\title{
Morphology and Distribution of Piptadeniastrum africanum (Hook.f.) Brenan and Cathormion altissimum (Hook.f.) Hutch. \& Dandy in Bayelsa State, Nigeria
}

\author{
Felix Okponanabofa Youkparigha* ${ }^{1}$, Bio Louis Nyananyo ${ }^{2}$ and Ayodele Adelusi Oyedeji ${ }^{1}$ \\ ${ }^{*}$ Department of Biological Sciences, Faculty of Science, Niger Delta University, Wilberforce Island, Bayelsa \\ State, Nigeria \\ ${ }^{2}$ Department of Plant Science and Biotechnology, Faculty of Science, University of Port Harcourt, Port \\ Harcourt, Rivers State, Nigeria
}

*Corresponding Author: Felix Okponanabofa Youkparigha, Department of Biological Sciences, Faculty of Science, Niger Delta University, Wilberforce Island, Bayelsa State, Nigeria

\begin{abstract}
This study assessed the morphology and distribution of Piptadeniastrum africanum (Hook.f.) Brenan and Cathormion altissimum (Hook.f.) Hutch. \& Dandy in Bayelsa state, Nigeria. Field study was carried in 36 communities across the 8 Local Government Areas in Bayelsa state from 2014 - 2018. The morphological characteristics were studied based on physical observations. The study found that the two plants are characteristically different based height, number of pinnae and leaflets, length and of seeds. Other distinguishing morphological characteristics are the smooth or spiny nature of their stems and the petals arrangement. The study also found that $C$. altissimum is evenly present in the riverine communities when compared to $P$. africanum. The decline in the relative abundance of $P$. africanum is due to over exploitation as a result of its premium value as timber species for construction and carpentry words. The study has been able to resolve the problematic taxonomy of the plants among some indigenous people of Bayelsa state who claim that the plants are the same, existing as upland and water species or one is male and the other is female. Again, there is the need for the conservation of these plant species within the locality especially $P$. africanum.
\end{abstract}

Keywords: Bayelsa state, Cathormion altissimum, Distribution, Morphology, Piptadeniastrum africanum

\section{INTRODUCTION}

Piptadeniastrum africanum (Hook.f.) Brenan is a tropical rain forest tree that can grow up to $45-50 \mathrm{~m}$ high and 3-5 $\mathrm{m}$ in girth. The plant has conspicuous plank-like buttresses, straight bole, with fine fernlike foliage. The plant also bears seeds of about $20-25 \mathrm{~mm}$ usually attached to the margin of the pod by a slender thread running from the middle and each is provided with wings that are papery, dark brown, and elongated (Brenan, 1955; Nyananyo, 2006).

The wood of $P$. africanum is very important in the construction/ carpentry industry for building of bridges, flooring, cabinets, canoe etc (Burkill, 1995; Jiofack, 2008; Fern, 2014). Different parts (root, bark and leaves) of $P$. africanum are commonly used in traditional medicine. Decoctions made with the bark of the plant is used for the treatment of cough, bronchitis, headache, mental disorder, haemorrhoids, genito-urinary infections, stomach-ache, dysmenorrhea, male impotence among others (Burkill, 1995; Fern, 2014).

Cathormion altissimum (Hook.f.) Hutch. \& Dandy is a deciduous tree found in riverine and fresh swamp water forests. The plant can grow up to $15 \mathrm{~m}$ in height. The young ones of the plant usually have spines. The plant bears fruit in pods which are usually twisted into the shape of a coil and constricted between the one-seeded segments (Keay, 1989; Royal Botanic Garden, 2018). The plant bears fruit from February to March and July to November (Keay, 1989). In Bayelsa state, the tree is common in the seasonally flooded forests.

The seed of $C$. altissimum is fermented and used as soup condiment in some part of Nigeria (Lemmens, 2006; Jolaoso et al., 2012). Decoctions made with the bark of plant is used for the treatment of tooth-ache, stomach-ache and pulmonary infections, while decoction made from the leaf is used is used as vapour bath to treat cold (Lemmens, 2006). 
P. africanum is of great interest due to its wide range of ethnobotanical uses - domestic, social and agricultural applications. Thus studies have concentrated on its chemical constituents and their usefulness to man (Ateufack et al., 2015; Owoeye et al., 2018). Consequently, there are comparatively few taxonomic studies that are necessary to clear the doubts that surround its problematic taxonomic status both locally and globally. Names such as Piptadeniastrum manni Oliver with an unresolved status and low confidence level is currently placed in the Plant List (2010), though placed as a species of the genus Piptadeniastrum Brenan in TROPICOS (2013). Moreover, reports of certain varieties of Piptadeniastrum africanum such as Piptadeniastrum africanum var. africanum and Piptadeniastrum africanum var. brachysperma Pellergr exist in literature (The Plant List, 2013). Piptadeniastrum africanum (Hook.f.) Brenan is endemic to tropical Africa. In the Niger Delta, it occurs on river banks in the riverine areas of the rain forest (Nyananyo, 2006). Some indigenous people claim that $P$. africanum and $C$. altissimum are same. As such there appears to be confusion about the taxonomic status of both plants. Some are of the opinion that one of them is male while the other is female.

In Bayelsa state, there is excessive exploitation of timber trees due to easier means of transportation as hinterlands are rapidly getting connected by roads. This is causing a speedy depletion of timber tree species populations especially in the coastal regions which were once rich in these tree species.This could lead to extinction of endemic tree species and endanger those that are vulnerable (Oguntala et al., 2000; Nodza et al., 2013). Trees such as $P$. africanum that has high demand for canoe carving and timber products is being affected by over exploitation with little or no control measures. Therefore, this study aimed at assessing the morphological characteristics and distribution of $P$. africanum and $C$. altissimum in Bayelsa state, Nigeria.

\section{MATERIALS AND MethodS}

\subsection{Study Area}

The study was carried out in Bayelsa State which is made up of eight Local Government Areas (Figure 1). The state is located within latitudes $04^{\circ} 15^{\prime}$ North and $05^{\circ} 23^{\prime}$ south and longitudes $05^{\circ} 22^{\prime}$ West and $06^{\circ} 45^{\prime}$ East. It is bounded by Delta State on the North, Rivers State on the East and on the west and south by the Atlantic Ocean (Figure 1). There are several surface waters in the state which are called by different names including rivers, streams, creeks, creeklets, rivulets based on their sizes. The water table in the area is quite high which varies according to the season (Agedah et al., 2015). The rate of water flooding in the area has increased in recent times with most coastal communities being submerged almost on annual bases. In these coastal communities, the rate of lumbering has also increased. The timber products, often called planks, are moved through the water ways to land and then transported within and outside the state. The timber species in forests within the state are now becoming rare partly due to extensive exploitation with little or no control/regulation measures on the part of the state.

\subsection{Sample Collection And Identification}

Field trips were under taken to all the local government areas of Bayelsa state (Figure 1) to assess the distribution of P.africanum and C. altissimum in the area. The plant specimens were identified at the Forest Herbarium Ibadan of the Forestry Research Institute of Nigeria (FRIN) and the Herbarium of the Department of Plant Science and Biotechnology, University of Port Harcourt, Rivers State. Voucher Specimens of the plants were deposited in these herbaria for reference and further studies.

\subsection{Morphological Studies}

Morphological studies involved physical observation, counting and measurement of both qualitative and quantitative diagnostic characters of the stems, leaves, flowers and fruits of the plants under study. The basic morphological characteristics of both plants studied include habit, height, number of pinnae, number of leaflets, length of leaflet, shape of leaf apex, colour of flowers, length of pods, width of pods, length of seeds, number of seeds, ovary, petals, rachis, stem and root.

\subsection{Distribution studies}

The plants were qualitatively distributed based on their occurrence in 36 communities and the adjoining forests across the 8 Local Government Areas. Plants available only in distant forests or special reserves within towns were designated as "+"; plants sighted scarcely in nearby forests are designated as "+ +"; plants sighted easily in nearby forests are designated as "+ + +"; and plants sighted commonly within town and nearby forests are designated as "++++". On the overall, a plot of 
the distribution of both plants was made and a distribution map of the plants in the study area was constructed.

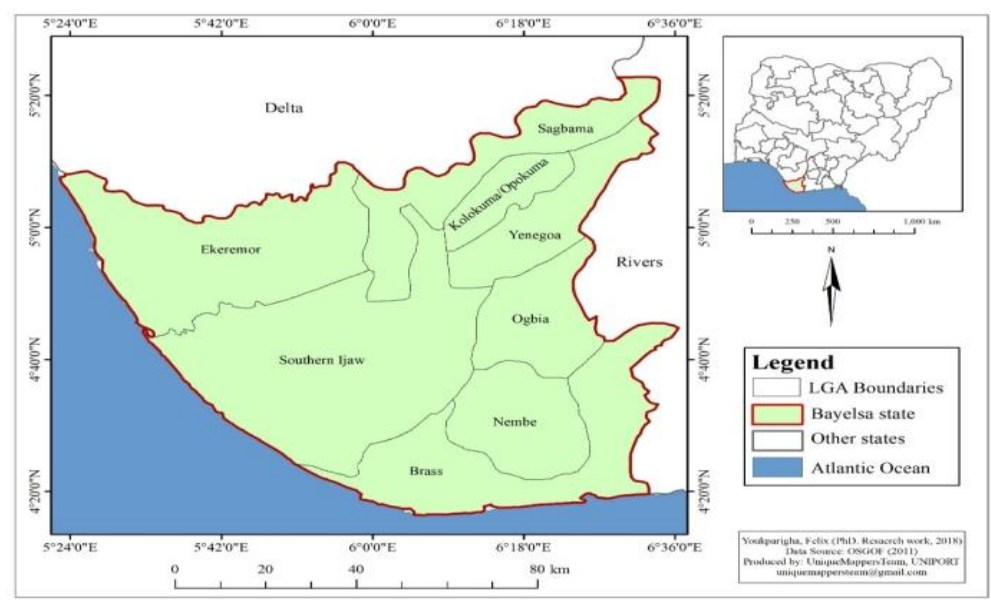

Figure1. Map of Bayelsa State, Showing the Local Government Areas

\section{RESULTS AND DISCUSSION}

The stems of the plants are different.P. africanum has a smooth and clear stem, while the stem of $C$. altissimum has spines especially in the juvenile stage (Figure 2). The root of $C$. altissimum is chractistically different from that of $P$. africanum which has planklike, broad, root butressess (Figure 2). Figure 3 presents the morphological chractristics of leaves and pod of $P$. africanum and $C$. altissimum.

The pods of $C$. Altissimum are coil-shaped, while $P$. africanum has lanceolate pods. For $P$. africanum and $C$. altissimum the colour of flower is Yellowish white and white respectively (Figure 3), length of pods is $20-30 \mathrm{~cm}$ and $10-28 \mathrm{~cm}$ respectively, width of pods is $1.5-3 \mathrm{~cm}$ and $1.3-3 \mathrm{~cm}$ respectively, length of seed is $8-9 \mathrm{~mm}$ and $6.5-7 \mathrm{~mm}$ respectively, number of seed is $8-9$ and $12-20$ (Table 1). Both plants ( $P$. africanum and $C$. altissimum) have varying heights, number of pinnae and leaflets which are characteristically higher in P. africanum. The shape of leaf apices of both plants is Obtuse. The ovaries of $P$. africanum and $C$. altissimum are both superior. The petals of $P$. africanum are free and oblong to lanceolate, while they make a tubular corolla in $C$. altissimum. Based on habits, $P$. africanum is a tree while $C$. altissimum could be a Shrub or tree (Table 1).

Table1. Important Morphological Features of P. Africanum and C. Altissimum

\begin{tabular}{|c|c|c|}
\hline Morphological character & P. africanum & C.altissimum \\
\hline Habit & Tree & Shrub or tree \\
\hline Height & $45-50 \mathrm{~m}$ & $5-35 \mathrm{~m}$ \\
\hline Number of pinnae & $10-19$ pairs & $11-22 \mathrm{pairs}$ \\
\hline Number of leaflets & $25-60$ pairs & $7-15 \mathrm{~mm}$ \\
\hline Length of leaflet & $1.5-8.5 \mathrm{~mm}$ & Obtuse \\
\hline Shape of leaf apex & Obtuse & white \\
\hline Colour of flowers & Yellowish white & $1.3-3 \mathrm{~cm}$ \\
\hline Length of pods & $20-30 \mathrm{~cm}$ & $6.5-7 \mathrm{~mm}$ \\
\hline Width of pods & $1.5-3 \mathrm{~cm}$ & $12-20$ seeds \\
\hline Length of seeds & $3-9.5 \mathrm{~mm}$ & superior \\
\hline Number of seeds & $8-9$ seeds & Tubular corolla \\
\hline Ovary & Superior, ellipsoid & Cushion shaped glands \\
\hline Petals & Free, oblong to lanceolate & often spinous \\
\hline Rachis & Absence of glands & Not plank-like \\
\hline Stem & Not spinous & \\
\hline Root & Large,thin, plank-like buttresses & \\
\hline
\end{tabular}

The morphological characteristics of P.africanum (Hook. f.) Brenan has been well described by several author such as William (1951), Keay (1989), Nyananyo (2006), Jiofack (2008). Similarly, Hutchinson and Dalziel (1958), Bingham et al. (2017) and Royal Botanic Garden (2018) have described the morphological features of C.altissimum (Hook. f.) Hutch. \& Dandy. 
Morphological characters are features of external form. They are useful in providing clues for practical plant identification on the field. Morphological characters were the first evidences used for classification by plant systematists before the emergence of anatomical, phytochemical and molecular evidence. The reason was due to the ease of observation of morphological characters found in both the vegetative and reproductive parts of plants (Judd et al., 2012).However, morphological approach to taxonomy suffers some disadvantages such as the difficulty in ascertaining reproductively isolated species which are nearly or completely morphologically indistinguishable; and the difficulty in differentiating between environmental influences and genetic variation on the phenotype of an organism (Hillis, 1987). Based on the morphological chracteristics, both plant is chracteristically different.

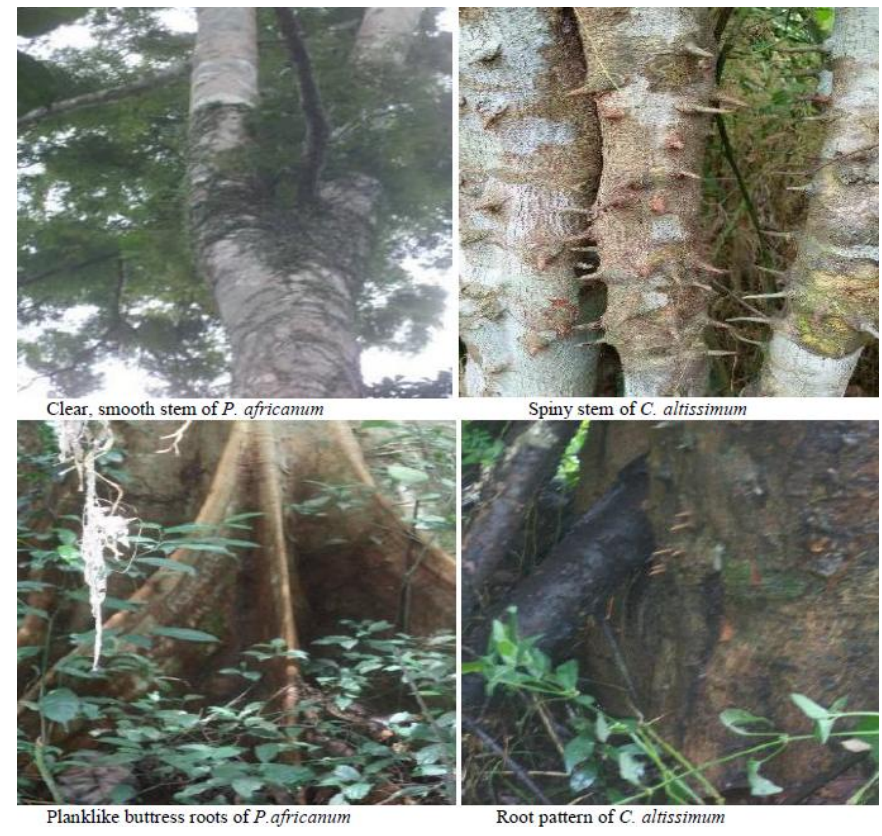

Figure2. Morphology of The Root And Stem-Bark of P. Africanum and C. Altissimum

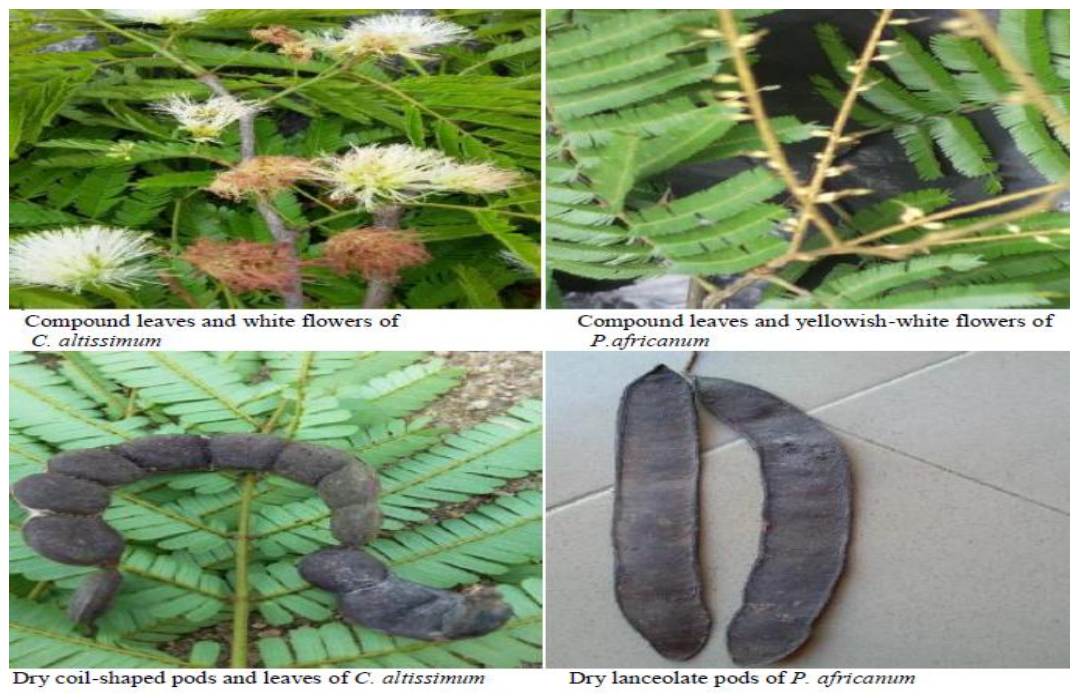

Figure3. Morphology of leaves and pods of P. Africanum and C. Altissimum

The distribution $P$. africanum and $C$. altissimumin Bayelsa state, Nigeria is presented in Table 2 and Figure 4.The field survey of the area of study showed that $P$. africanum, though not threatened, is not common but widely distributed (Jiofack, 2008; ILDIS, 2013). Based on the distribution C. altissimum has higher occurrence rate in most of the communities studied compared to $P$. africanum (Figure 4).P. africanum is now a rare wood in the market because it is now available in very distant forests with a very high cost of procurement that many lumberjacks are not willing to pay. The result of the availability of this plant mostly in very distant forest is the poor knowledge about this plant for the average Bayelsan, especially the youths. Only elders and youths that work particularly in the wood industry have some knowledge of this very important plant. 
Morphology and Distribution of Piptadeniastrum africanum (Hook.f.) Brenan and Cathormion altissimum (Hook.f.) Hutch. \& Dandy in Bayelsa State, Nigeria

Table2. Distribution of P. Africanum and C. Altissimumin the Study Area with Their Coordinates

\begin{tabular}{|c|c|c|c|c|}
\hline Forest/Community & LGA & P. africanum & C.altissimum & Date \\
\hline Agrisaba & Nembe & +++ & +++ & $22 / 09 / 15$ \\
\hline Aguobiri & Southern Ijaw & + & +++ & $16 / 06 / 18$ \\
\hline Akakumama & Nembe & + & ++ & $24 / 10 / 15$ \\
\hline Akipelai & Ogbia & +++ & +++ & $14 / 06 / 18$ \\
\hline Akumoni-Okordia & Yenagoa & + & +++ & $20 / 06 / 18$ \\
\hline Amassoma & Southern Ijaw & ++ & +++ & $06 / 06 / 18$ \\
\hline Amatolo & Sagbama & + & +++ & $07 / 06 / 18$ \\
\hline Angalabiri & Sagbama & + & +++ & $25 / 10 / 15$ \\
\hline Anyama & Southern Ijaw & ++ & +++ & $16 / 06 / 18$ \\
\hline Anyamasa & Ekeremor & + & +++ & $18 / 06 / 18$ \\
\hline Beletie-Ama & Brass & +++ & ++++ & $15 / 06 / 18$ \\
\hline Biseni & Yenagoa & ++ & +++ & $20 / 06 / 18$ \\
\hline Bomadi-Ekpetiama & Yenagoa & + & +++ & $06 / 06 / 18$ \\
\hline Egeibiri & Southern Ijaw & ++ & +++ & $16 / 06 / 18$ \\
\hline Egweama & Brass & ++ & ++++ & $15 / 06 / 18$ \\
\hline Emadike & Ogbia & ++ & +++ & $25 / 05 / 18$ \\
\hline Emeyal & Ogbia & + & +++ & $07 / 05 / 14$ \\
\hline Epebu & Ogbia & ++ & +++ & $09 / 06 / 18$ \\
\hline Etiema & Nembe & ++ & +++ & $02 / 09 / 15$ \\
\hline Ewoama & Brass & ++ & +++ & $14 / 06 / 18$ \\
\hline 1gbedi & Kolokuma/Opokuma & + & +++ & $07 / 05 / 14$ \\
\hline Igbogene & Yenagoa & + & +++ & $25 / 09 / 16$ \\
\hline Isampou & Ekeremor & + & +++ & $18 / 06 / 18$ \\
\hline Ogbia & Ogbia & + & +++ & $14 / 06 / 18$ \\
\hline Ogbolomabiri & Nembe & ++ & +++ & $14 / 06 / 18$ \\
\hline Ogobiri & Sagbama & ++ & +++ & $04 / 08 / 14$ \\
\hline Okpoama & Brass & +++ & +++ & $14 / 06 / 18$ \\
\hline Okunbiri & Sagbama & ++ & +++ & $06 / 06 / 18$ \\
\hline Opume & Ogbia & ++ & +++ & $16 / 06 / 18$ \\
\hline Otatubu & Nembe & + & +++ & $02 / 09 / 15$ \\
\hline Otuasega & Ogbia & + & +++ & $14 / 09 / 15$ \\
\hline Otuoke & Ogbia & + & +++ & $07 / 05 / 14$ \\
\hline Sabagreia & Kolokuma/Opokuma & + & +++ & $08 / 06 / 18$ \\
\hline Toru-Ebeni & Southern Ijaw & + & +++ & $08 / 06 / 18$ \\
\hline Toru-Orua & Sagbama & ++ & +++ & $18 / 06 / 18$ \\
\hline Twon-Brass & Brass & ++ & +++ & $14 / 06 / 18$ \\
\hline
\end{tabular}

Legend: + (Available only in distant forests or special reserves within town) +++ (sighted scarcely in nearby forests $) ;+++$ (sighted easily in nearby forests) ++++ (sighted commonly within town and nearby forests)

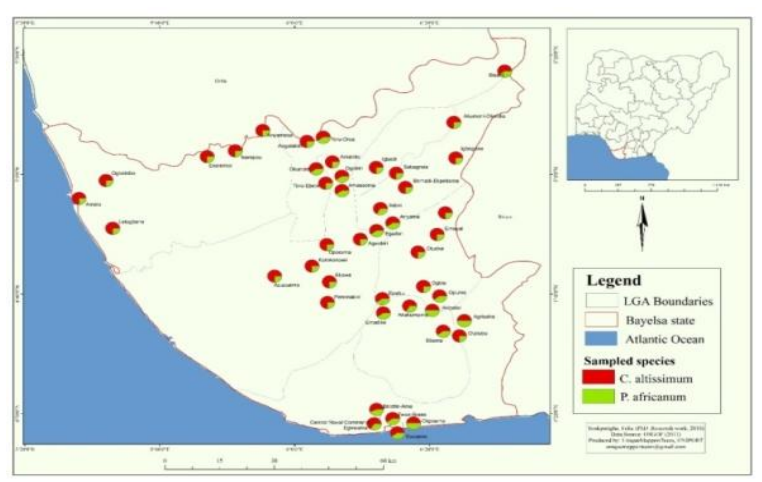

Figure4. Map showing the Distribution of P.africanum and C. altissimum in Bayelsa State

\section{Conclusion}

The study has been able to clear the doubt that P.africanum and C. altissimum are same. It is clear that P.africanum and $C$. altissimum belong to different genera based on their morphological characteristics. The distribution of Piptadeniastrum in Bayelsa State and its taxonomic status carried 
out in this study revealed that it is widely distributed in Bayelsa State and it is monotypic. The only species in the genus is Piptadeniastrum africanum (Hooker filius) Brenan, basionym: Piptadenia africana Hooker filius. The study found that $P$. africanum is fast depleting in our forest like many other valuable timber species. For the purpose of knowledge for future generations, there is need for botanical gardens or forest reserves to conserve these plants in Bayelsa State.

\section{ACKNOWLEDGEMENT}

This paper is based on part of post graduate project work of F.O.Youkparigha supervised by Prof. Prof. B.L. Nyananyo at the Niger Delta University, Wilberforce Island, Nigeria.

\section{REFERENCES}

[1] Agedah, E. C., Ineyougha, E. R., Izah, S. C., \& Orutugu, L.A. (2015). Enumeration of total heterotrophic bacteria and some physico-chemical characteristics of surface water used for drinking sources in Wilberforce Island, Nigeria. Journal of Environmental Treatment Techniques, 3(1), 28 - 34.

[2] Ateufack, G., Mokam, E. C. M., Mbiantcha, M., Feudjio, R. B. D., David, N., \& Kamanyi, A. (2015). Gastroprotective and ulcer healing effects of Piptadeniastrumafricanumon experimentally induced gastric ulcers in rats. BMC Complement Altern Med. 15, 214. doi: 10.1186/s12906-015-0713-5.

[3] Bingham, M. G., Willemen, A., Wursten, B. T., Ballings, P., \& Hyde, M. A. (2017). Flora of Zambia: Species information: Cathormion altissimum var. altissimum. Retrieved from: https://www.zambiaflora.com/species data/species.php? species_id=186380. Accessed [28-04-2018].

[4] Brenan, J.P.M. (1955). Piptadeniastrumafricanum. Kew Bulletin, 179

[5] Burkill, H.M. (1995). The useful Plants of West Tropical Africa. Edn. 2, Vol. 3, Families J-1. Royal Botanic Gardens, Kew, Richmond, Surrey, England. 857pp.

[6] Fern, K. (2014) Piptadeniastrumafricanum. Useful Tropical Plants Database. Retrieved from: https://www.Tropical.thefern.infoviewtropical.php?id=Piptadeniastrum+africanum. Accessed [17-072016].

[7] Hillis, D.M. (1987). Molecular versus Morphological approaches toSystematics. Annual Review of Ecology and Systematics, 18, 23-42.

[8] Hutchinson, J. and Dalziel, J.M. (1958): Flora of West Tropical Africa. 2nd edition Vol. 1, Part 2. Revised by Keay, R.W.J. Crown Agents for Oversea Governments and Administrations, MillBank, London. 532pp.

[9] International Legume Database and Information Service (2013). Piptadeniastrumafricanum. Retrievedfrom: https://www.legumes.online.net/ildis/aweb/td001/td00096.html. Accessed [28-01-2016].

[10] Jiofack, T.R.B. (2008). Piptadeniastrumafricanum (Hook.f.) Brenan. Timbers Boisd'oeuvre. Retrievedfrom: Https??database.Prota.org/PROTAhtml/Piptadeniastrum\%20africanum_En.html. Accessed [04-04-2014].

[11] Jolaoso, A.A., Ajayi, J.O., Ogunmuyiwa, S.I.O., \& Albert, O.M. (2012). Changes in Functional Properties as a Measure of Biochemical Deterioration of Oso (Fermented Seeds of Cathormion Altissimum). Journal of Emerging Trends in Engineering and Applied Sciences 3(4), 608-613.

[12] Judd, W.S., Campbell, C.S., Kellog, E.A., Stevens, P.F., \&Donoghue, M.J. (2012). Plant Systematics: a phylogenetic approach 2ndedition. Pp5569-7581.Retrievedfrom: https://www.botany.wisc.edu /fieldbotany /pdf/juddchpt4.pdf.Accessed [14-04-2016].

[13] Keay, R.W.J. (1989). Trees of Nigeria. A revised version of Nigerian Trees (1960, 1964) by R.J.W. Keay, C.F.A. Onochie and D.P. Stanfield. Clarendon Press, Oxford, United Kingdom. 476pp.

[14] Lemmens, R.H.M.J. (2006). Albizia altissima Hook.f. Record for PROTA4U. Louppe, D. Oteng-Amoako, A.A. \& Brink, M. (Editors). PROTA (Plant Resources for Tropical Africa), Waganengen, Netherlands. Retrieved from: https://www.prota4u.org/search.asp. Accessed [18-04-2018].

[15] Nodza, I.G., Abdulhameed, A., \& Abdullahi, M.B. (2013). A Checklist and Ethnobotanical Assessment of Tree Species of Abubakar Tafawa Balewa University (ATBU) Yelwa Campus Bauchi, Nigeria. International Journal of Botany, 9 (2), 55-63

[16] Nyananyo, B.L. (2006). Plants from the Niger Delta. Onyoma Research publications, Nigeria. 403pp.

[17] Oguntala, A.B., Soladoye, M.O., and Ugbogu, O.A. (2000). Endangered tree species of the Nigerian flora. The Nigerian Journal of Forestry. Forestry Association of Nigeria. 30 (1\&2), 15-21

[18] Owoeye, E.A., Ogboru R.O., Bakpolor, V.R., \& Omobude, D.E. (2018). Phytochemical screening and proximate analysis of the bark of Piptadeniastrum africanum Hook (Fabaceae). World News of Natural Sciences, 19, 135-141. 
[19] Royal Botanic Garden (2018). An introduction of the trees from the North of the Republic of Congo. Retrieved from: https://www.congotrees.rbge.org.uk/species/ details/Cathormion-altissimum. Accessed [23-08-2018].

[20] The Plant List (2010): Piptadeniastrum. Available from: https://www.theplantlist. Org/ Accessed [19-052013].

[21] The Plant List (2013). Available from: https://www.theplantlist.org/Accessed [19-05-2013]

[22] TROPICOS (2013). Piptadeniastrummanni Oliv.Missouri Botanical Garden .Retrieved from: https://www.tropicos .org/Name/13069459.Accessed [19-05-2013].

[23] William, J.E. (1951). The indigenous trees of Uganda protectorate. Robert Maclehose \& Company. The University Press, Glasgow. Pp. 228-230.

Citation: Youkparigha, F, et.al., (2019)."Morphology and Distribution of Piptadeniastrum africanum (Hook.f.) Brenan and Cathormion altissimum (Hook.f.) Hutch. \& Dandy in Bayelsa State, Nigeria". International Journal of Advanced Research in Botany (IJARB), 5(2), pp.18-24. DOI: http:// dx.doi.org/10.20431/2455-4316.0502002

Copyright: (C) 2019 Authors. This is an open-access article distributed under the terms of the Creative Commons Attribution License, which permits unrestricted use, distribution, and reproduction in any medium, provided the original author and source are credited 